\title{
Old honey bee brood combs are more infested by the mite Varroa destructor than are new brood combs
}

\author{
Giancarlo A. PICCIRILLO ${ }^{\mathrm{a}, \mathrm{b}}$, David De JONG ${ }^{\mathrm{c} *}$ \\ a Departamento de Biologia/Área Entomologia, FFCLRP-USP, 14040-901 Ribeirão Preto, SP, Brasil \\ b Departamento Fitosanitario, Museo de Artrópodos (MALUZ), La Universidad del Zulia, AA. 525, Maracaibo, \\ Venezuela \\ c Departamento de Genética, FMRP-USP, 14.049-900 Ribeirão Preto, SP, Brasil
}

(Received 12 June 2003; revised 18 August 2003; accepted 12 September 2003)

\begin{abstract}
Varroa destructor preferentially invades larger honey bee brood cells. Consequently, it was expected that brood in old combs with reduced-size cells would be less infested than the brood in new comb cells. An old brood comb was placed in each of eight Africanized honey bee colonies, along with a new, naturally constructed comb (without comb foundation). The mean percentage of brood cells infested with $V$. destructor was significantly higher in the old combs $(22.6 \%)$, than in the new combs $(9.75 \%)$, even though the inside width of the cells was significantly smaller in the old $(4.58 \mathrm{~mm})$ than in the new combs $(4.85 \mathrm{~mm})$. Within the range where there was an overlap in the width of brood cells between old and new combs, which was from 4.5 to $4.9 \mathrm{~mm}$, the old comb cells were over four times more frequently infested with mites than were the new comb cells. Some factor other than cell size makes old brood comb cells much more attractive to $V$. destructor than newly constructed brood comb.
\end{abstract}

Varroa destructor / natural comb / comb cell size / infestation / old comb

\section{INTRODUCTION}

Historically, beekeepers and bee researchers have been concerned with the condition and structure of the wax combs that honey bees use for brood production and for honey storage. There has been considerable controversy about the size of the comb cells, and how cell size affects bee size and colony production. Cell size can be controlled by the size of the cell base patterns pressed into wax comb foundation. As larger cells result in larger bees, there has been a tendency to "force" bees to build comb of larger sizes by providing oversize foundation due to a poorly supported notion that larger bees produce more honey (Coggshall and Morse, 1984). Yet more recently there has been some concern that a "natural size" bee may actually be better for honey production and disease resistance. After combs have been used for brood production for several brood cycles, the comb becomes darker and the cells tend to become smaller (Winston, 1987). The cell walls thicken with an accumulation of debris from larval cocoons and other detritus (Coggshall and Morse, 1984). The volume of the repeatedly used brood cells becomes significantly smaller, resulting in smaller bees. Old combs also have increased disease problems due to accumulations of microorganisms, such as fungi, bacteria, protozoa (Nosema apis Zander) and viruses (Bailey and Ball, 1991). One disease problem that has been linked to brood comb cell size is infestation with Varroa destructor Anderson \& Trueman (De Jong et al., 1982). The choice of a brood comb cell by a $V$. destructor female is influenced by the

\footnotetext{
* Corresponding author: ddjong@ fmrp.usp.br
} 
size of the brood cell (Issa et al., 1993). It is well known that $V$. destructor preferentially attacks drone over worker brood (Fuchs, 1990). This makes sense since the mites produce more offspring in drone brood. Drone brood cells are about $70 \%$ larger in area than worker brood cells. Even among worker brood cells, larger cells attract more mites (Message and Gonçalves, 1995; Piccirillo and De Jong, 2003). Taller (protruding) brood cells also attract more mites (De Jong and Morse, 1988; De Ruitjer and Calis, 1988; Kuenen and Calderone, 2000). However, the mechanisms by which mites use cell size to choose among brood cells are still unknown. Colonies kept on new comb that they had produced from foundation were found to produce more brood and larger bees than those supplied with old comb; however, the survivorship of the brood was higher in the old comb (Berry and Delaplane, 2001). As old dark brood combs normally have the smallest-size cells, and mite infestations in worker brood increase with comb cell size (Piccirillo and De Jong, 2003), we decided to compare mite infestation levels in worker brood reared in old comb with reduced cell size versus that found in new (natural-sized) comb recently built by the bees (without comb foundation).

\section{MATERIALS AND METHODS}

Eight Africanized honey bee colonies maintained in single deep 10-frame Langstroth hives were studied from August 1999 to November 2000 in our university apiary in Ribeirão Preto, SP, Brazil. The colonies contained about 20000 bees, and were fed with sucrose syrup during dearth periods. Each colony contained a new comb, naturally built without comb foundation, by the bees of the same colony. It had never been used for brood rearing before. An old, dark Africanized honey bee comb, with thick cell walls and relatively small cells, was also supplied to each colony. The two combs were placed side by side in the middle of the brood nest. The queens laid eggs in these two types of combs and brood was present at the same time in both combs. There was no drone brood at this time; consequently the mites could only infest worker brood.

The combs were examined daily, and then taken to the laboratory when the new adult workers began to emerge. As soon as a bee began to open its cell capping, the operculum was completely removed with a forceps. The bee was removed and the interior of the cell and the bee were carefully examined for $V$. destructor, with the aid of an otoscope. The number of dark colored adult females was registered for each infested brood cell. The inside width of each cell was measured with a caliper with a resolution of $0.01 \mathrm{~mm}$. Three measurements were made of each cell, corresponding to the distance between the parallel sides of the hexagonal cell in all three directions. These three measures were averaged to provide a mean cell width. Both infested and uninfested cells were measured.

\section{RESULTS}

The mean percentage of infested brood cells (mean of the number of infested cells divided by the number of cells that were inspected in each colony) was significantly higher in the old comb $(22.6 \pm 13.1 \%)$ than in the new comb $(9.75 \pm 3.99 \%)$ in the eight colonies (Tab. I, paired $t$-test on arcsine (square root of the proportion of infested cells), $t=$ 4.99, $P=0.0016)$. The mean infestation rate (the number of dark colored adult female mites per brood cell) was also measured, and it was greater in all eight colonies (Tab. I). However this data on the number of mites is not directly comparable, because we waited until the bees had matured and emerged from their brood cells; the first female progeny can also become darkened at this stage. Consequently, our counts could include some of the first female progeny, along with the original females. Nevertheless, the tendency towards higher infestations in old comb was the same as that found for the percentage infested cells.

The mean inner width of the old comb cells $(4.58 \pm 0.06 \mathrm{~mm})$ was significantly smaller than that of the new combs $(4.85 \pm 0.06 \mathrm{~mm})$. Though the cells in old brood combs were generally smaller, there was some overlap with cell size in new brood combs, so we were able to compare the percentage cells infested with $V$. destructor -in old and new combs in the cell width intervals from 4.51-4.9 mm (Tab. II). There was no significant relationship between the percentage cells infested with mites in each of the different colonies and the number of old versus new cells within each size range $(\mathrm{r}=$ $-0.197, P=0.64$, Pearson's correlation coefficient), so the data from the eight colonies was analyzed together. The mean percentage of 
Table I. Number of brood cells invaded and infestation rates by the mite Varroa destructor (number of adult female mites, divided by the number of brood cells examined) obtained from new naturally built worker comb and from old dark worker brood comb in Africanized honey bee colonies.

\begin{tabular}{|c|c|c|c|c|c|c|}
\hline \multirow[b]{2}{*}{ Colony } & \multicolumn{3}{|c|}{ Old comb } & \multicolumn{3}{|c|}{ New Africanized comb } \\
\hline & $\begin{array}{c}\text { Cells } \\
\text { inspected }\end{array}$ & $\begin{array}{c}\text { Number cells } \\
\text { infested }\end{array}$ & $\begin{array}{c}\text { Infestation } \\
\text { (No. mites/100 } \\
\text { cells)* }\end{array}$ & $\begin{array}{c}\text { Cells } \\
\text { inspected }\end{array}$ & $\begin{array}{l}\text { Number cells } \\
\text { infested }\end{array}$ & $\begin{array}{c}\text { Infestation } \\
\text { (No. mites/100 } \\
\text { cells) } *\end{array}$ \\
\hline 69 & 53 & 8 & 20.8 & 63 & 8 & 15.6 \\
\hline 71 & 200 & 49 & 30.0 & 115 & 10 & 10.4 \\
\hline 43 & 90 & 9 & 15.6 & 90 & 7 & 13.3 \\
\hline 47 & 100 & 21 & 34.0 & 100 & 12 & 18.0 \\
\hline 66 & 100 & 30 & 49.0 & 100 & 15 & 23.0 \\
\hline 73 & 100 & 17 & 19.0 & 100 & 7 & 9.0 \\
\hline 74 & 100 & 26 & 54.0 & 100 & 15 & 25.0 \\
\hline 117 & 100 & 21 & 27.0 & 100 & 4 & 5.0 \\
\hline
\end{tabular}

* Some cells had more than one dark colored female mite; this would include the original female (or females) that had invaded the brood cell, plus the oldest female progeny.

Table II. Comparison of the percentage of worker brood cells infested with Varroa destructor in old and new combs (pooled data from eight Africanized honey bee colonies), with data divided into $0.1 \mathrm{~mm}$ comb cell (inner) width intervals. Only the cell width intervals where there was overlap between the two types of combs and that had more than 20 cells in each of the two types of comb are included here. $(n)=$ number of cells in each cell-size category.

\begin{tabular}{ccccc}
\hline \multicolumn{3}{c}{ Old comb } & \multicolumn{3}{c}{ New comb } \\
\hline $\begin{array}{c}\text { Cell } \\
\text { width } \\
(\mathrm{mm})\end{array}$ & $\begin{array}{c}\text { \% cells } \\
\text { infested }\end{array}$ & $\begin{array}{c}(\mathrm{n}) \\
\text { cells }\end{array}$ & $\begin{array}{c}\text { \% cells } \\
\text { infested }\end{array}$ & $\begin{array}{c}(\mathrm{n}) \\
\text { cells }\end{array}$ \\
\hline $4.51-4.6$ & 14 & 309 & 2.7 & 37 \\
$4.61-4.7$ & 30 & 185 & 7.2 & 97 \\
$4.71-4.8$ & 46 & 46 & 7.6 & 157 \\
$4.81-4.9$ & 62 & 21 & 12 & 267 \\
\hline
\end{tabular}

infested cells was significantly higher in the old than in the new cells within each size range $(P=0.036$, paired sample t-test $)$.

\section{DISCUSSION}

We had expected that there would be fewer $V$. destructor in the smaller brood cells in the old combs than in the relatively larger brood cells in the new combs, as previous experiments had indicated a positive correlation between cell size and infestation rate (Message and Gonçalves, 1995; Piccirillo and De Jong, 2003). Indeed, the tendency towards higher infestation in wider cells was maintained for each type of comb $(P<0.05$, Pearson's correlation coefficient). Drone brood, which is reared in large brood cells, is also considerably more infested by $V$. destructor than is worker brood (Fuchs, 1990). Cell size at least partly explains this attraction, as drone brood reared in drone cells is significantly more infested than brood reared in worker-size cells in the same colony (Issa et al., 1993).

However the cells in the old combs were much more infested than those in the new (naturally built) combs (Tab. I), even though the former were significantly smaller. The old comb cells were four to over five times as infested as the new brood comb cells, when the same $1 / 10 \mathrm{~mm}$ cell width intervals were compared (Tab. II). It is clear that these mites strongly preferred old worker brood comb cells to new worker brood cells. However, the cues that the mites use to make this discrimination are unknown.

There is a general impression by beekeepers that bees kept on old combs have more problems with diseases. Koenig et al. (1986) found that colonies with old combs had more 
chalkbrood, caused by the fungus Ascosphaera apis. Old combs are also more affected by nosema disease caused by Nosema apis (Bailey and Ball, 1991) and American foulbrood caused by Paenibacillus larvae subsp. larvae (Gilliam, 1985), both of which can be disseminated from colony to colony through contaminated wax comb. However, Erickson et al. (1998) found higher infestation rates with A. woodi (Rennie) in colonies with new combs than in those with old combs $(5.2 \%$ vs. $1.2 \%$ respectively). Recently, Hassan (2000) reported that female $V$. destructor reproduced more in new than in old brood combs.

Old comb cells contain many substances that absorb into the wax (Coggshall and Morse, 1984). They may contain brood pheromones (Free and Winder, 1983), cuticular compounds from the larvae (Calderone and Lin, 2001), aliphatic alcohols and aldehydes of the honey bee cocoon (Donzé et al., 1998), or other semiochemicals (Trouiller et al., 1994); these substances could be attractants or stimulants for $V$. destructor. However, the higher mite infestations found in brood reared on old comb could also be an indirect effect of a tendency of nurse bees to spend more time on old comb. Other characteristics of the bee larva, of the wax comb, or of the larval food, could also be factors that influence the behavior of mites seeking brood cells for reproduction. Kraus et al. (1994) found that artificial substances impregnated into wax comb foundation resulted in increased mite infestation rates in the bee brood. It is not clear how the mites would benefit from their preference for old comb. Mite reproduction is significantly reduced when reared in artificial cells that have been used previously by other females, or when these cells are impregnated with extracts of artificial cells that had been infested (Nazzi and Milani, 1996; Nazzi et al., 2002). Based on these findings, one would expect the mites to avoid old, previously infested brood comb cells, instead of preferentially infesting brood in old comb. In our experiment we had no way to determine whether the old cells had been previously infested or not, however these combs had been in use for many years, and the individual cells most likely had been infested several times.

The strong preference that we found for old comb cells could provide new ways to control this important bee parasite. If the four-times greater preference by the mites extends to combs that are impregnated with old comb extracts, these mites could be preferentially attracted to treated combs, and subsequently destroyed. The mites' preference for old comb may also provide clues about how these mites are stimulated to invade brood cells and begin their reproductive cycle.

\section{ACKNOWLEDGEMENTS}

The authors thank Adelino Penatti for technical assistance in the apiary. The Brazilian national science foundation $(\mathrm{CNPq})$ provided financial assistance and FONACIT (Venezuela) provided a scholarship for G.A.P.

Résumé - Les vieux rayons de couvain d'abeilles sont plus infestés par l'acarien Varroa destructor que les rayons neufs. L'acarien parasite Varroa destructor infeste de préférence les cellules de couvain larges plutôt que les étroites. Puisque les cellules des vieux rayons ont une largeur réduite due à l'accumulation des cocons larvaires et des autres débris, on s'attendait à ce que les vieux rayons soient moins infestés que les neufs. Dans 8 colonies d'abeilles africanisées, on a placé un vieux rayon de couvain d'ouvrières, qui avait des cellules aux parois épaissies et à la largeur interne réduite, et un rayon d'ouvrières neuf que les abeilles de chaque colonie test avait construit naturellement sans cire gaufrée. A chaque émergence d'ouvrière on a enregistré le nombre d'acariens femelles adultes de couleur foncée présent dans les cellules infestées. Le pourcentage moyen des cellules infestées par l'acarien était significativement $(P=$ $0,01)$ plus élevé dans les vieux rayons $(22,6 \%)$ que dans les neufs $(9,75 \%)$, même si la largeur interne des cellules était significativement $(P<0,001)$ plus petite dans les vieux rayons $(4,58 \mathrm{~mm})$ que dans les neufs $(4,85 \mathrm{~mm})$. Dans chaque colonie, le couvain du vieux rayon était plus infesté que celui du rayon neuf. Dans le domaine de largeur compris entre 4,5 et $4,9 \mathrm{~mm}$, que l'on trouvait à la fois dans les vieux rayons et dans les neufs, les cellules des vieux rayons étaient plus de 4 fois plus infestées que celles des rayons neufs. Nous en concluons qu'il existe certains aspects dans les vieux rayons ou le couvain d'ouvrières élevé dans des vieux rayons qui rendent ce couvain plus attractif pour les femelles de $V$. destructor qui cherchent à pénétrer dans les cellules, que le couvain présent dans les rayons fraîchement construits.

Varroa destructor / rayon naturel / taille des cellules / infestation / vieux rayon 
Zusammenfassung - Alte Brutwaben der Honigbienen sind häufiger von der Milbe Varroa destructor befallen als neue Brutwaben. Die parasitische Bienenmilbe Varroa destructor (Acari: Varroidae) befällt im Brutnest der Honigbienen bevorzugt größere als engere Zellen. Alte Brutwaben bestehen auf Grund mehrerer aufeinander liegender Puppenhäutchen und anderer Reste aus Zellen mit kleinerem Durchmesser. Deshalb wurde vermutet, dass die Brut in alten Waben weniger befallen wird als die in größeren frischgebauten Wabenzellen. Eine alte Arbeiterinnenbrutwabe mit verdickten Zellwänden und kleinem Innendurchmesser wurde in je eines von 8 Völkern der afrikanisierten Honigbiene gestellt; und zwar neben eine frische Wabe mit Arbeiterinnenzellen, die jeweils von den Testvölkern ohne Vorgabe von Mittelwänden selbst gebaut worden war. Nach dem Schlupfbeginn der jungen Arbeiterinnen wurde die Zahl von dunkelfarbigen Milbenweibchen in den befallenen Zellen im Moment des Schlupfes bestimmt. Der innere Durchmesser von befallenen und nicht befallenen Brutzellen wurde bestimmt. Der durchschnittliche Prozentsatz der von Milben befallenen Zellen in den alten Waben war mit 22,6\% signifikant höher $(P=0,01)$ als in den neugebauten Waben $(9,75 \%)$, obwohl der Innendurchmesser mit $4,58 \mathrm{~mm}$ in den alten Zellen signifikant $(P<0,001)$ kleiner war als in den neuen Waben $(4,85 \mathrm{~mm})$. In jedem Volk war die Brut in den alten Waben stärker befallen als in den neuen. Im Bereich von 4,5 bis 4,9 $\mathrm{mm}$ gab es eine Überlappung in der Größe der Brutzellen bei den alten und neuen Waben, in diesen Fällen war die Brut in den alten Zellen 4 mal so häufig mit adulten $V$. destructor Weibchen befallen als die in den frischen Zellen. Daraus schließen wir, dass einige Eigenschaften der alten Wabe oder der in alten Waben aufgezogene Arbeiterinnenbrut diese für eindringende Milbenweibchen attraktiver macht als Arbeiterinnenbrut in frischgebauten Waben.

Varroa destructor / junge Wabe / Größe der Wabenzelle / Befall / alte Wabe

\section{REFERENCES}

Bailey L., Ball B.V. (1991) Honey bee pathology. Harcourt Brace Jovanovich; Sidcup, Kent, UK, p. 193.

Berry J.A., Delaplane K.S. (2001) Effect of comb age on honey bee colony growth and brood survivorship, J. Apic. Res. 40, 3-8.

Calderone N.W., Lin S. (2001) Behavioural responses of Varroa destructor (Acari: Varroidae) to extracts of larvae, cocoons and brood food of worker and drone honey bees, Apis mellifera (Hymenoptera: Apidae), Physiol. Entomol. 26, $341-350$.
Coggshall W.L., Morse R.A. (1984) Beeswax. Production, Harvesting, Processing and Products, Wicwas Press, Ithaca, New York, p. 192.

De Jong D., Morse R.A. (1988) Utilisation of raised brood cells of the honey bee, Apis mellifera (Hymenoptera: Apidae), by the mite Varroa jacobsoni (Acarina: Varroidae), Entomol. Gen. 14, 103-106.

De Jong D., Morse R.A., Eickwort G.C. (1982) Mite pests of honey bees, Annu. Rev. Entomol. 27, 229-252.

De Ruijter A., Calis J.N.M. (1988) Distribution of Varroa jacobsoni female mites in honey bee worker brood cells of normal and manipulated depth (Acarina: Varroidae), Entomol. Gen. 14, 107-109.

Donzé G., Schnyder-Candrian S., Bogdanov S., Diehl P.A., Guerin P.M., Kilchenmann V., Monachon F. (1998) Aliphatic alcohols and aldehydes of the honey bee cocoon induce arrestment behavior in Varroa jacobsoni (Acari: Mesostigmata), an ectoparasite of Apis mellifera, Arch. Insect Biochem. 37, 129-145.

Erickson E.H., Atmowidjojo A., King A., King J. (1998) Effect of "New" vs. "Old" wax brood combs on honey bee tracheal mite populations in North Dakota, Am. Bee J. 141, 672-673.

Free J.B., Winder M.E. (1983) Brood recognition by honey bee (Apis mellifera) workers, Anim. Behav. 31, 539-545.

Fuchs S. (1990) Preference for drone brood cells by Varroa jacobsoni Oud. in colonies of Apis mellifera carnica, Apidologie 21, 193-199.

Gilliam M. (1985) Microbes from apiarian sources: Bacillus spp. in frass of the greater wax moth, J. Invertebr. Pathol. 45, 218-224.

Hassan R.A. (2000) Studies on some factors affecting Varroa mite reproduction, Abstracts from the 2nd Int. Conf. on Africanized Honey Bees and Bee Mites, April 10-12, 2000, Tucson, AZ., Am. Bee J. 140,745 .

Issa M.R., De Jong D., Gonçalves L.S. (1993) Reproductive strategies of the mite Varroa jacobsoni (Mesostigmata, Varroidae): Influence of larva type and comb cell size on honey bee brood infestation rates, Braz. J. Genet. 16, 219 224.

Koenig J.P., Boush G.M., Erickson, E.H. (1986) Effect of type of brood comb on chalk brood disease in honeybee colonies, J. Apic. Res. 25, $58-62$.

Kraus B., Koeniger N., Fuchs S. (1994) Screening of substances for their effect on Varroa jacobsoni - attractiveness, repellency, toxicity and masking effects of etheral oils, J. Apic. Res. 33, 34-43.

Kuenen L.P.S., Calderone N.W. (2000) Varroa mite infestations in elevated honey bee brood cells: 
Effect of context and caste, J. Insect Behav. 13, 201-215.

Message D., Gonçalves L.S. (1995) Effect of the size of worker brood cells of africanized honey bees on infestation and reproduction of the ectoparasitic mite Varroa jacobsoni Oud, Apidologie 26, 381-386.

Nazzi J.A., Milani N. (1996) The presence of inhibitors of the reproduction of Varroa jacobsoni Oud (Gamasida: Varroidae) in infested cells, Exp. Appl. Acarol. 20, 617-623.

Nazzi J.A., Milani N., Della Vedova G. (2002) (Z)-8heptadecene from infested cells reduces the reproduction of Varroa destructor under laboratory conditions, J. Chem. Ecol. 28, 21812190.

Piccirillo G.A., De Jong D. (2003) The influence of brood comb cell size on the reproductive behavior of the ectoparasitic mite Varroa destructor in Africanized honey bee colonies, Genet. Mol. Res. $2,36-42$.

Trouiller J., Arnold G., Chappe B., Leconte Y., Billion A., Masson C. (1994) The kairomonal esters attractive to the Varroa jacobsoni mite in the queen brood, Apidologie 25, 314-321.

Winston M.L. (1987) The biology of the honeybee, Harvard University Press, Cambridge, Massachusetts, London, England, p. 281. 